\title{
MEMBANGUN KARAKTER BANGSA MELALUI KETELADANAN
}

\author{
Alfurqan, M.Ag
}

\begin{abstract}
Abstrak
Membangun karakter bangsa sesungguhnya tidak butuh konsep yang muluk-muluk dengan program-program yang menelan biaya yang besar. Yang penting adalah bagaimana menanamkan nilai-nilai keteladan dalam kehidupan berbangsa melalui bimbingan para pemimpin dan keteladanan di setiap tindakannya. Konsep yang bagus dengan dana yang sangat besar, jika anakanak bangsa, tidak diberi contoh nyata sehingga bisa menjadikan manusia Indonesia yang berkarakter mulia. Kita sering membicarakan karakter bangsa, tetapi hanya sebatas retorika. Tidak sedikitpun tercermin dalam kehidupan sehari-hari, terutama dari pemimpin bangsa. Padahal, pendidikan karakter bangsa itu efektif dengan keteladanan.
\end{abstract}

Kata kunci : Karakter, bangsa, keteladanan

\section{A. Pendahuluan}

Proses membangun sebuah bangsa tidaklah cukup hanya dalam esensi fisik belaka. Perlu adanya suatu orientasi yang sedemikian sehingga esensi fisik tersebut berlanjut dalam suatu internalisasi untuk menuju pada pembangunan tata nilai atau sebaliknya pembangunan yang berorientasi pada tatanan fisik tersebut dijiwai oleh semangat peningkatan tata nilai sosio kemasyarakatan dan budaya, meskipun yang kedua ini umumnya lebih sulit dibandingkan dengan yang pertama. Sehingga pembangunan dan pembinaan karakter suatu bangsa menjadi suatu istilah yang semakin sering diungkapkan sekaligus di perlukan pemahamannya yang lebih baik, khususnya dalam menjadikan pembangunan fisik suatu bangsa sebagai salah satu instrumen dalam pembinaan karakter manusianya.

Sisi lain yang tidak kalah pentingnya adalah pengaruh dari kemajuan kapasitas berpikir manusia, yang umumnya diartikulasikan dalam bentuk kemajuan ilmu pengetahuan dan teknologi. Terutama dalam hal ini adalah teknologi informasi dan telekomunikasi. Kedua jenis teknologi ini secara sangat radikal telah mengakselerasi proses interaksi antar manusia dari berbagai bangsa dan memberikan dampak adanya amalgamasi berbagai kepentingan lintas 
bangsa atau lazim dikenal dengan globalisasi. Salah satu unsur yang sejatinya sudah ada dalam proses amalgamasi kepentingan antar manusia dari jaman dahulu kala adalah daya saing atau competitiveness.

Membangunan bangsa dan membangunan karakter bangsa adalah dua istilah yang sering saling dipertautkan antara satu dengan lainnya. Hal ini sangat wajar karena artikulasi sebuah bangsa memang berbeda dengan sebuah benda fisik biasa, misalnya bangunan atau jembatan (M.Hatta Rajasa, 2007). Jika sebuah bangunan atau jembatan runtuh, maka keruntuhannya dapat tampak secara fisik, antara lain dengan berserakannya bagian bagian jembatan atau bangunan tersebut.

Hal tersebut berbeda dengan bangsa, sebuah bangsa adalah kumpulan dari tata nilai (values). Sendi sendi yang menopang sebuah bangsa umumnya adalah berupa karakter dan mentalitas rakyatnya yang menjadi pondasi yang kukuh dari tata nilai bangsa tersebut. Keruntuhan sebuah bangsa umumnya ditandai dengan semakin lunturnya nilai nilai bangsa tersebut, walaupun secara fisik bangsa tersebut sebenarnya masih eksis.

Fenomena globalisasi adalah dinamika yang paling strategis dan membawa pengaruh dalam tata nilai dari berbagai bangsa termasuk bangsa Indonesia. Sebagian kalangan menganggapnya sebagai ancaman yang berpotensi untuk menggulung tata nilai dan tradisi bangsa kita dan menggantinya dengan tata nilai pragmatisme dan populerisme asing. Di pihak lain, globalisasi adalah juga sebuah fenomena alami, sebuah fragmen dari perkembangan proses peradaban yang harus kita lalui bersama.

\section{B. Karakter Bangsa}

Kata karakter sering diberi padanan kata watak, tabiat, perangai atau akhlak. Dalam bahasa Inggris character diberi arti a distinctive differentiating mark, tanda yang membedakan secara tersendiri. Karakter adalah keakuan rohaniah, yang nampak dalam keseluruhan sikap dan perilaku, yang dipengaruhi oleh bakat, atau potensi dalam diri dan lingkungan. Dengan demikian karakter adalah suatu kualitas yang mantap dan khusus (pembeda) yang terbentuk dalam kehidupan individu yang menentukan sikap dalam mengadakan reaksi terhadap rangsangan dengan tanpa mempedulikan situasi dan kondisi. Karakter secara harfiah adalah stempel, atau yang tercetak, yang terbentuk dipengaruhi oleh faktor endogeen/dalam diri dan faktor 
exogeen/luar diri. Sebagai contoh rakyat Indonesia semula dikenal bersikap ramah, memiliki hospitalitas yang tinggi, suka membantu dan peduli terhadap lingkungan, dan sikap baik yang lain; dewasa ini telah luntur tergerus arus global, berubah menjadi sikap yang kurang terpuji, seperti mementingkan diri sendiri, mencaci maki pihak lain, mencari kesalahan pihak lain, tidak bersahabat dan sebagainya. Hal ini mungkin saja didorong oleh keinginan untuk bersaing sebagai salah satu kompetensi yang harus dikembangkan dalam era globalisasi. Karakter dapat berubah akibat pengaruh lingkungan, oleh karena itu perlu usaha membangun karakter dan menjaganya agar tidak terpengaruh oleh hal-hal yang menyesatkan dan menjerumuskan.

Ada ahli yang berpendapat bahwa manusia tercipta dalam perbedaan secara individual, hal ini nampak dalam tingkat kecerdasan, dalam kemampuan ungkapan emosional dan manifestasi kemauan. Manusia juga dibekali oleh Tuhan dengan kemampuan untuk membedakan yang benar dan yang salah, yang baik dan yang buruk, meski ukuran benar-salah dan baik-buruk mengalami perkembangan sesuai dengan pertumbuhan yang dialami oleh manusia dan tantangan zamannya. Dengan demikian moral dan karakter pada manusia melekat secara kodrati, namun selalu mengalami perkembangan sesuai dengan pertumbuhan dan tantangan yang dihadapi. Seperti yang dipesankan oleh Bung Karno kepada kita bangsa Indonesia, bahwa tugas berat untuk mengisi kemerdekaan adalah membangun karakter bangsa. Apabila pembangunan karakter bangsa ini tidak berhasil, maka bangsa Indonesia akan menjadi bangsa kuli (H. Soemarno Soedarsono, 2009). Pernyataan Bung Karno ini menunjukkan pentingnya pendidikan dan pembangunan karakter demi tegak dan kokohnya jati diri bangsa agar mampu bersaing di dunia global.

Karakter membentuk ciri khas individu atau suatu entitas suatu kualitas yang menentukan suatu individu atau entitas, sedemikian rupa sehingga diakui sebagai suatu pribadi yang membedakan dengan individu atau entitas lain. Kualitas yang menggambarkan suatu karakter bersifat unik, khas, yang mencerminkan pribadi individu atau entitas dimaksud, yang akan selalu nampak secara konsisten dalam sikap dan perilaku individu atau entitas dalam menghadapi setiap permasalahan.

Belakangan ini timbul kerisauan di sebagian kalangan masyarakat terhadap perilaku manusia Indonesia yang dinilai menyimpang dari akhlak atau karakter mulia. Tindakan kekerasan dan pelanggaran HAM, perilaku amoral dan runtuhnya budi pekerti luhur, semaunya 
dan tidak disiplin, anarkhisme dan ketidaksabaran, korupsi, ketidakjujuran dan budaya nerabas, rentannya kemandirian dan jati diri bangsa, terus menghiasai kehidupan bangsa kita (Sardiman AM, 2010). Mereka telah tidak mampu lagi membedakan antara perilaku yang terhormat dan terpuji dengan perbuatan yang hina dan tidak bermartabat. Mereka tidak memahami atau tidak peduli terhadap perbuatan yang dinilai memalukan dan hina. Mereka juga tidak peduli atau tidak mampu membedakan antara perbuatan yang mulia dan nista. Sebagai akibat lebih lanjut tata hubungan masyarakat menjadi sangat rancu.

Masyarakat masa depan yang bercirikan semakin rasional, kritis, dan obyektif, maka menuntut pelayanan yang tidak saja mementingkan simbol-simbol atau lambang-lambang tetapi menuntut kualitas yang sebenarnya. Kehidupan masa depan yang disebut sebagai era modern, maka akan terjadi persaingan secara terbuka. Dalam persaingan itu, maka siapa saja yang mampu menjadikan dirinya kuat dan unggul, maka merekalah yang akan memenangkan persaingan itu.

Dalam menjalankan hidupnya manusia tidak terlepas dari nilai dan norma yang mewarnai kehidupannya. Sejak zaman purba manusia selalu mendambakan keadilan, kejujuran, kesejahteraan, keberadaban dan sebagainya. Orang selalu membedakan antara perbuatan yang baik dan buruk, yang benar dan salah, yang adil dan yang dzalim Mereka sangat peduli dengan nilai kehidupan. Mereka mendambakan agar anggota masyarakat bersikap dan bertingkah laku sesuai dengan nilai yang dipilihnya. Nilai adalah kualitas yang melekat pada suatu hal ihwal, perkara atau subyek tertentu yang berakibat dipilih atau tidaknya hal ihwal, perkara atau subyek tersebut dalam kehidupan masyarakat.

Suatu pemerintahan yang adil selalu menjadi dambaan rakyat. Lukisan yang indah selalu diburu oleh para kolektor lukisan. Orang yang jujur selalu dihargai oleh masyarakatnya, dan sebagainya. Apabila nilai dapat terwujud, maka akan menimbulkan rasa puas diri pada masyarakat, yang bemuara pada rasa tenteram, nyaman, sejahtera dan bahagia. Sayangnya pengertian terhadap suatu nilai sering, atau bahkan pada umumnya, belum satu faham. Suatu contoh bahwa ada yang berpendapat bahwa nilai itu bersifat subyektif, sangat tergantung siapa yang menyampaikannya; ada pula yang mengatakan nilai bersifat obyektif tidak tergantung pada subyek yang mengungkapkannya. Nilai melekat secara intrinsik tidak tergantung dari yang menggunakannya. 
Di samping itu masih terdapat perbedaan pengertian terhadap suatu nilai. Nilai adil, misalnya, memiliki pengertian yang sangat beraneka, sehingga sering terjadi perbedaan pendapat mengenai keadilan terhadap suatu hal ihwal atau perkara yang satu. Suatu perkara atau hal ihwal dapat dikatakan adil oleh pihak tertentu, secara bersamaan dikatakan tidak adil oleh pihak lain. Bagaimanapun, masyarakat sangat mendambakan nilai-nilai tertentu dan selalu berusaha untuk mewujudkannya.

Nilai yang dipergunakan sebagai ukuran untuk menentukan atau menilai suatu tingkah laku manusia disebut norma. Norma adalah berasal dari bahasa Latin yang artinya siku-siku, suatu alat untuk mengukur apakah suatu obyek tegak lurus atau miring. Demikian pula halnya dengan norma kehidupan, dipergunakan manusia sebagai pegangan atau ukuran dalam bersikap dan bertindak; apakah sikap dan tingkah lakunya tidak menyimpang dari nilai yang telah ditetapkan. Dalam hidup bermasyarakat, berbangsa dan bernegara dikenal berbagai norma, seperti norma agama, norma adat, norma moral, norma hukum dan sebagainya. Masing-masing mendukung nilai sesuai dengan bidangnya. Kaitan Karakter, Jatidiri, Nilai dan Norma Karakter, jatidiri, nilai dan norma perlu didudukkan secara tepat dan proporsional agar tidak terjadi kerancuan dan kakacauan dalam memanfaatkan dan menerapkannya baik dalam wacana maupun dalam praktek kehidupan. Setiap subyek, individu, atau entitas agar dapat diakui eksistensinya perlu memiliki identitas atau ciri khusus yang membedakan dengan subyek, individu atau entitas lain. Identitas atau ciri khusus yang telah mempribadi, menyatu dengan subyek, individu atau entitas tersebut disebut jatidiri Jatidiri ini akan menampakkan wajahnya dalam bentuk sikap dan perilaku subyek, individu atau entitas terhadap tantangan yang terkena pada dirinya. Apabila perilaku ini telah membaku sehingga tidak peduli pada situasi dan kondisi yang meliputinya, maka sikap dan perilaku tersebut berkembang menjadi karakter.

Dengan demikian jatidiri suatu subyek, individu atau suatu entitas akan menampakkan dalam karakter, yang akan termanifestasi dalam sikap dan perilaku dalam menyikapi permasalahan dan tantangan yang dihadapi. Kita kenal individu yang berkarakter teguh dan konsisten, ada yang memiliki karakter selalu berubah setiap saat, sehingga sukar sekali ditebak dan diperhitungkan. Yang pertama sering disebut berkarakter baja, sedang yang kedua berkarakter bunglon, atau tidak memiliki pendirian. Karakter merupakan perpaduan antara factor intern yang terdapat dalan diri individu dan faktor ekstern yakni lingkungan tempat individu berhubungan. Sebagai konsekuensinya, karakter mengandung nilai-nilai tertentu, yang biasanya 
bersumber dari nilai yang berkembang dalam masyarakat tempat individu hidup bermasyarakat, berbangsa dan bernegara. Sebagai akibat karakter akan mengalami perubahan, sedang jatidiri pada hakikatnya bersifat tetap. Meskipun perkembangan karakter tidak dibenarkan menyimpang dari nilai dasar yang menjadi ciri khas jatidiri. Dari uraian tersebut nampak jelas bahwa setiap individu atau entitas perlu memiliki jatidiri yang merupakan ciri khas yang membedakan dengan individu atau entitas yang lain. Jatidiri individu atau suatu entitas akan nampak dalam karakter individu atau entitas dimaksud. Karakter berisi nilai-nilai terpilih yang dipegang oleh individu atau entitas dalam menghadapi segala permasalahan. Nilai-nilai terpilih tersebut kemudian dijadikan pedoman dalam bersikap dan bertingkah laku sehingga menjadi faktor pengukur sikap dan perilaku individu atau entitas.

\section{Pentingnya Keteladanan}

Proses pendidikan keteladanan di mulai dari keluarga dan diajarkan pula di sekolah. Anak sudah harus diarahkan untuk mengikuti hal-hal baik yang dilakukan oleh para orang dewasa agar mereka mendapatkan contoh konkrit dari apa yang dilihatnya. Seorang anak adalah mesing foto copy yang canggih, apapun yang diperbuat oleh bapak dan ibunya maupun lingkungan keluarga akan di contoh oleh si anak, sekarang kemana si anak akan di arahkan? Oleh karena itu bijaklah dalam berbicara maupun bertindak, ingatlah dalam keluarga ada yang sedang menjiplak anda.

Pendidikan anak diawali dari rumah. Oleh karenanya semakin besar anak, sebagai orang tua harus semakin berhati-hati bertingkah laku \& berkata-kata, takut anak meniru yang buruk. Anak-anak adalah peniru yang baik.

Pendidikan keteladanan sebenarnya ada dalam rumah-rumah kita. Dia bersemayam dalam hati kita masing-masing, karena pada hakekatnya keteladanan muncul dari dalam diri. Hal itu terlihat dari bagaimana seorang ayah yang melindungi anak-anaknya dengan sepenuh hati dan sepenuh jiwa. Bagaimana seorang ibu yang menyayangi anak-anaknya dengan penuh kasih sayang dan belaian lembut seorang ibu. Semua itu mereka lakukan demi keberlangsungan hidup anak-anaknya. Ketika ayah dan ibu tak menjadi teladan bagi anak-anaknya. Ketika seorang 
kakak tak memberikan teladan kepada adiknya, dan ketika yang tua tak memberikan teladan kepada yang muda. Apa yang terjadi?

Kita tentu akan melihat bahwa budi pekerti telah hilang dari dalam diri. Mereka yang muda tentu akan mengikuti gaya orang tuanya. Bila orang tuanya baik, maka anak pun akan cenderung baik. Ketika orang tuanya jahat, maka anak pun akan berkecenderungan jahat pula. Pendidikan keteladanan harus dimulai dari keluarga. Para orang tua harus dapat memberikan keteladanan kepada anak-anaknya.

Ketika orang tua mengajak anaknya untuk beribadah, maka orang tuanya itu harus memberikan keteladanan lebih dulu. Jangan sekali-kali mengajak anak untuk beribadah, ketika orang tua tak melakukannya. Sebab bila itu terjadi anak akan protes dan cenderuang memaki dan mengumpat. Bisa saja keluar kalimat, “ayah saja tidak sholat, dan ibu saja tidak mengaji”. Pada akhirnya anak melihat kelakuan buruk orang tuanya. Anak akan cepat meniru apa yang dilakukan oleh kedua orang tuanya. Keteladanan positif pun tak terjadi.

Menjadi orang tua ideal perlu ilmu. Menjadi guru ideal juga perlu ilmu. jika orang tua dan guru mengamalkan ilmunya dengan benar, saya yakin keteladanan bisa diberikan pada anak. Sayangnya, banyak suami istri tidak mencari ilmu mendidik anak karena sibuk dengan urusan pemenuhan kebutuhan keluarga. Mereka mengandalkan guru di sekolah untuk mendidik anaknya. Namun, ternyata guru telanjur dipusingkan dengan urusan administrasi sekolah dan urusan keluarga. mereka hanya sempat mentransfer materi pelajaran tapi lupa menanamkan keteladanan. Kalau sudah begitu, semoga kita tidak termasuk golongan orang yang merugi.

Pendidikan keteladanan harus dipupuk dari anak masih usia dini. Tentu memori otaknya akan menyimpan semua hal baik yang dilihatnya. Tetapi bila kita sebagai orang tua tak memberikan keteladanan, maka jangan salahkan bila anak kita berkelakukan kurang ajar. Dalam dunia persekolahan kita, pendidikan keteladanan harus diberikan guru kepada anak didiknya. Menyatu dalam kurikulum yang bernama pendidikan karakter. Di sinilah fungsi mendidik itu diperkukan. Para peserta didik diajarkan bagaimana mencontoh hal-hal baik yang ada dalam kehidupannya sehari-hari.

Orang tua lupa bahwa mereka itu guru pertama bagi anaknya. Keluarga itu adalah sekolah pertama anak. Merah, putih, dan hitamnya anak tergantung pada orang tuanya. Sayangnya, urusan menddik anak dianggap sebagian orang tua hanyalah urusan guru di sekolah. 
Pendidik sebagai cermin. Orang mu'min adalah cermin bagi orang mu'min (yang lain). Jika ia melihat cela padanya maka diperbaikinya. (HR.Bukhari).

Pendidikan keteladanan akan berjalan dengan baik dalam dunia pendidikan bila kita sebagai orang tua, guru, dan dosen mampu memberikan keteladanan kepada anak-anaknya. Tak perlu ini dan itu dalam memberikan keteladanan, karena keteladanan itu sederhana. Sangat sederhana. Tetapi di antara kita sering tak melakukannya. Mengingat begitu penting guru dalam pendidikan, maka guru dituntut untuk memiliki kriteria-kriteria yang telah disebutkan diatas. Guru merupakan figur atau tokoh panutan peserta didik dalam mengambil semua nilai dan pemikiran tanpa memilih antara yang baik dengan yang buruk. Peserta didik memandang bahwa guru adalah satu-satunya sosok yang sangat disanjung. Maka didikan dari guru berpengaruh besar dalam memilih andil dalam membentuk kepribadian dan pemikiran peserta didik.

Pendidikan atau guru merupakan bagian pendidikan yang langsung berinteraksi dan bertanggung jawab dalam pengolahan sumber daya manusia. Secara langsung mengubah pola pikir dan meningkatkan prosuktifitas peserta didik melalui ilmu yang dikembangkan secara bersama-sama dengan komponen pendidikan lain. Oleh pendidikan dibuat lebih kreatif dalam memecahkan permasalahan peserta didik secara efektif dan efisien. Sehingga secara langsung maupun tidak langsung mampu mendorong kemajuan peserta didik.

Maman Faturrohman (2007) dalam buku Al-qur'an pendidikan dan pengajaran. Mengemukakan kondisi Ideal pendidik dan pengajar, antara lain :

- Telah mendapat pendidikan atau pengajaran. Seorang pendidik dan pengajar idealnya adalah seorang yang telah mendapat pendidikan atau pengajaran sebelum menjadi guru.

- Benar-benar menguasai ilmu. Seorang pendidikan dan pengajar, idealnya adalah seorang yang benar-benar menguasai ilmu, khususnya ilmu yang akan disampaikan kepada peserta didik. Sudah benar-benar menjiwai ilmu tersebut dan kebenaran ilmu teruji, termasuk oleh orang-orang di sekitar pendidik.

Menurut DN. Madley (1979) dalam buku Pendidikan Islam dalam Sistem Pendidikan Nasional di Indonesia mengatakan bahwa "Salah satu proses Asumsi yang melandasi keberhasilan guru dan pendidikan guru adalah penelitian berfokus pada sifat-sifat kepribadian guru. Kepribadian guru yang dapat menjadi suri teladanlah yang menjamin keberhasilannya 
mendidik anak". Faktor keteladanan yang seharusnya ada pada diri seorang guru adalah sebagai berikut:

1. Kesiapan untuk dinilai dan dievaluasi. Ini akan berdampak pada kehidupan sosial di masyarakat, karena ucapan, sikap, dan prilakunya menjadi sorotan dan teladan. Orang mu'min adalah cermin bagi orang mu'min (yang lain). Jika ia melihat cela padanya maka diperbaikinya. (HR.Bukhari).

2. Memiliki kompetensi Minimal. Maksudnya kompetensi ini bisa dijadikan cermin bagi dirinya maupun orang lain, dapat menumbuhkan dan menciptakan keteladan, terutama bagi peserta didiknya.

3. Memiliki Integritas. Integritas adalah adanya kesamaan antara ucapan dan tindakan atau satu kata satu perbuatan. Letaknya pada kualitas istiqomah yang berupa komitmen dan konsistensi terhadap profesi yang diembannya.

Al-Maghribi bin as-said al-maghribi dalam buku bebegini seharusnya mendidik anak (2004), mengemukakan kriteria-kriteria seorang pendidik teladan menurut Al-Quran dan sunnah Rasulullah SAW adalah sebagai berikut:

- Pemaaf dan tenang;

- Lemah lembut dan menjauhi sifat kasar dalam bermuamalah;

- Berhati penyayang;

- Ketakwaan;

- Selalu berdoa untuk anak;

- Lemah lembut dalam bermuamalah dengan anak;

- Menjauhi sikap marah ;

- Bersikap adil dan tidak pilih kasih.

Mendidik dengan Keteladanan kepada anak didik dapat diksanakan dalam bentuk sebagai berikut:

1. Kesederhanaan. Guru harus pandai membawakan diri sehingga terkesan sederhana dan bersahaja tetapi punya kepiawaian dalam mengajar.

2. Kedekatan. Kedekatan hubungan guru dengan siswa sangat ini hampir tidak ada. Padahal dengan kedekatan ikatan antara guru dan murid dapat terjalin.

3. Suasana silahturahim. Fungsi silahturahim antara lain adalah menumbuhkan rasa kecintaan dan rasa saling peduli. Jika silahturahim diterapkan dalam suasana pembelajaran tentu akan kondusif baik antara guru dengan siswa maupun antara siswa dengan siswa. 
4. Pelayanan Maksimal. Maksudnya tugas utama guru adalah menfasilitasi murid, atau guru sebagai fasilitator. Memfasilitasi yang dimaksud pada hakikatnya sebagai perwujudan bentuk pelayanan guru kepada murid (guru sebagai pelayan) Guru dapat mengadopsi filosofi jawa dalam menerima, menghormati, dan melayani tamu dalam suatu perjamuan dengan empat sikap dan prilaku, yaitu: (1) aruh (tegur sapa) murid harus disambut ramah oleh guru; (2) gupuh (sibuk-repot) guru penuh perhatian dan melayani murid dengan sungguh-sungguh; (3) lungguh (duduk-tempat) Guru menyiapkan pembelajaran dalam suasana yang kondusif; (4) suguh (hidangan-sajian) Murid dapat menikmati pembelajaran yang menarik dari guru bagaikan mendapat hidangan yang lezat dalam suatu perjamuan.

\section{Pembangunan Bangsa yang Berkarakter melalui keteladanan}

Munculnnya gagasan program pendidikan karakter di Indonesia bisa dimklumi. Sebab, selama in dapat dirasakan bahwa proses pendidikan belum membangun manusia Indonesia yang berkarakter. Hal yang perlu kita renungkan dalam melihat persoalan yang melilit bangsa ini sebenarnya adalah menyangkut akhlak, moral, atau etika. Tatkala seseorang terlalu mencintai jabatan, maka ia akan rela mengeluarkan uang berapapun jumlahnya. Maka, uang dianggap menjadi sangat penting. Tanpa uang jabatan tidak akan diperoleh.Sementara lainnya, tanpa mengaitkan dengan jabatan, seseorang sangat menyukai uang. Memiliki banyak uang diangap berprestise dan aman. Hidupnya akan dihargai orang dan merasa terjamin. Oleh karena itu, sehari-hari aktivitasnya hanya mencari uang, apapun caranya ditempuh. Bagi mereka yang terpenting uang terkumpul sebanyak-banyaknya. Tidak peduli, usahanya itu ternyata merugikan orang lain.

Budayawaan Muchtar Lubis pernah memmberikan deskripsi karakter bangsa Indonesia yang sangat negatif. Lebih jauh, Muchtar Lubis (2001) dalam bukunya Manusia Indonesia mendeskripsikan ciri-ciri utama yang melekat pada manusia Indonesia sebagai berikut:

1. Hipokritis alias munafik. Berpura-pura, lain di muka lain di belakang, merupakan sebuah ciri utama manusia Indonesia sejak mereka dipaksa untuk menyembunyikan apa yang sebenarnya dirasakan karena takut akan mendapatkan ganjaran yang membahayakan pada dirinya oleh kekuatan yang terkuat saat itu.

2. Segan dan enggan bertanggungjawab atas perbuatannya, putusannya, kelakuannya, pikirannya dan sebagainya. 
3. Jiwa feodal. Meskipunsalah satu tujuan revolusi kemerdekaan Indonesia adal;ah untuk membebaskan manusia Indoensia dari feodalisme, tapi feodalisme dalam bentuk baru makin berkembang dalam diri dan masyarakat Indonesia.

4. Percaya kepada takhayul. Dari zaman dahulu sampai sekarang masih ada yang percaya pada batu, gunung, keris, pisau dan lainnya. Kemudian kita membuat mantera dan semboyan baru, orde baru, the rule of law, pemberantasan korupsi, kemakmuran yang merata dan adil dan insan pembangunan.

5. Manusia Indoensia mempunyaikarakter lemah. Meraka kurang kuat memeprtahankan atau memeperjuangkan keyakinannya, mudah dipaksa,apalagi jika dipaksa mereka bersedia mengubah keyakinannya demi untuk survive.

6. Cenderung boros. Dia senang berpakaian bagus, mewah, berpesta. Hari ini ciri ini menjelma dalam bentuk memakai barang buatan luar negeri, main golf, singkatnya seba mahal.

Sementara itu, pemimpin bangsa selalu menyebut bahwa persoalan di negeri ini terletak pada ekonomi, demokrasi dan keadilan. Pandangan itu tidak terlalu salah. Memang di negeri ini membutuhkan peningkatan ekonomi, demokrasi dan keadilan. Kiranya pandangan itu tidak ada yang membantahnya. Namun yang perlu dilihat kembali adalah, apakah rendahnya tingkat ekonomi, demokrasi, dan keadilan itu merupakan sebab atau justru sebagai akibat.

Terjadinya kasus-kasus korupsi, suap menyuap, sogok menyogok, mafia, pemalsuan dokumen pemerintah dan lain-lain itu, sebenarnya adalah oleh karena didorong oleh kecintaan mereka terhadap jabatan dan harta kekayaan itu. Bahkan konflik-konflik di antara para elite bangsa yang terjadi selama ini, misalnya dalam kasus bank century, Gayus Tambunan, pemalsuan dokumen, konflik intern partai, dan lain-lain adalah terkait dengan uang. Akibatnya, para pejabat tinggi dipanggil dan diperiksa oleh KPK dan atau kejaksaan. Semua itu bukan menyangkut persoalan besar, semisal terkait falsafat hidup atau idiologi, melainkan menyangkut hal sederhana, yaitu terlalu mencintai jabatan dan uang.

Secara jelas nampak bahwa perbuatan korup, sogok menyogok, suap menyuap, justru terjadi di kalangan elite dan atau orang-orang yang sudah bergelimang dengan harta. Mereka korupsi bukan karena miskin, atau untuk mempertahankan hidup, melainkan karena kecintaan terhadap jabatan dan harta itu. Dengan demikian, maka lebih tepat dikatakan bahwa keadaan itu disebabkan oleh karena merosotnya akhlak sementara elite bangsa. 
Persoalan korupsi, suap menyuap, sogok menyogok dan berbagai mafia itu adalah persoalan akhlak, maka cara menanggulanginya adalah juga melalui pembenahan akhlak. Akhlak bangsa ini harus diperbaiki. Caranya adalah melalui pendidikan yang benar. Pendidikan yang benar sebetulnya telah dicontohkan oleh Rasulullah. Tinggal mau atau tidak melaksanakannya. Nabi berhasil membangun masyarakat Madinah juga menggunakan pendekatan akhlak, hingga sampai-sampai dikatakan bahwa ia diutus hanya untuk menyempurnakan akhlak yang mulia.

Banyak pendidik percaya, Karkter suatu bangsa terkait dengan prestasi yang diraih oleh bangsa itu dalam berbagai bidang kehidupan. Dr. Ratna Megawangi (2007) dalam bukunya Semua berkakar pada karakter mencotohkan bagaimana kesuksesan cina dalam menerapkan pendidikan karakter sejak awal tahun 1980-an. Menurutnya, pendidikan karakter adalah untuk mengukir akhlak melalui proses knowing the good, loving the good, and acting the good. Yakni suatu proses pendidikan yang melibatkan aspek kognitif, emosi dan fisik,. Sehingga akhlak mulia bisa diukir menjadi habit of mind, heart, and hands.

Para pemimpin hendaknya bisa menjadi pribadi yang senantiasa melakukan intropeksi dalam kehidupannya sebagai panutan dan menjadi cermin bagi rakyatnya. Cermin secara filosofi memiliki makna sebagai berikut:

1. Tempat yang tepat untuk intropeksi.

2. Menerima dan menampakkan apa adanya

3. Menerima kapan pun dan dalam keadaan apa pun.

4. Tidak pilih kasih/ tidak deskriminatif

5 Pendidik sebagai cermin.

Memperbaiki akhlak, harus melalui pendidikan yang benar, ketauladanan dari para pemimpin, tegaknya hukum, dan menjaga keadilan. Bangsa Indonesia adalah bangsa yang religius. Oleh karena itu cara yang tepat untuk menyelesaikan persoalan bangsa ini adalah, agar semua secara bersama-sama elite dan rakyat, segera menunaikan agamanya masing-masing secara utuh dan sebaik-baiknya. Insya Allah, akhlak akan menjadi terpelihara, dan berbagai persoalan bangsa akan terselesaikan. Pendidikan karakter tidak berhasil jika hanya retorika. Suksesnya pendidikan karakter justru butuh keteladanan. 


\section{E. Penutup}

Dari penjelasan di atas dapat diambil kesimpulan bahwa membangun karakter bangsa sesungguhnya tidak butuh konsep yang muluk-muluk dengan program-program yang menelan biaya yang besar. Yang penting adalah bagaimana menanamkan nilai-nilai keteladan dalam kehidupan berbangsa melalui bimbingan para pemimpin dan keteladanan di setiap tindakannya.

Akan sia-sia saja konsep yang bagus dengan dana yang sangat besar, jika anak-anak bangsa, tidak diberi contoh nyata sehingga bisa menjadikan manusia Indonesia yang berkarakter mulia. Kita sering membicarakan karakter bangsa, tetapi hanya sebatas retorika. Tidak sedikitpun tercermin dalam kehidupan sehari-hari, terutama dari pemimpin bangsa. Padahal, pendidikan karakter bangsa itu efektif dengan keteladanan. Wallahua'lam bis showab.

\section{DAFTAR PUSTAKA}

Alfurqan, Rahman R, and Rezi M. (2017) Pendidikan Orang Dewasa Yang Dikembangkan Rasullullah. Islam Transformatif : Journal of Islamic Studies 1, no. 1 Hal 15-29. https://doi.org/10.30983/it.v1i1.327

Alfurqan. (2015). Konsep Pendidikan Islam Pondok Pesantren Dan Upaya Pembenahannya. Vol.1 Hal. 209. UNP Press.

AM, Sardiman. (2010). Revitalisasi Peran Pembelajaran IPS dalam Pembentukan Karakter Bangsa, Cakrawala Pendidikan. Edisi khusus 2010. Yogyakarta: ISPI bekerja sama dengan UNY

Bin as-Said Al-Magribi, Al-Magribi. 2004. Kaifa Turabbi Waladan” diterjemahkan oleh Zaenal Abidin dengan Judul : Begini Seharusnya Mendidik Anak. Jakarta: Darul Haq

Daulay, Haidar Putra. 1979. Pendidikan Islam dalam Sistem Pendidikan Nasional di Indonesia (Cet.I). Jakarta : Kencana 
Faturrohman, Maman. 2007. Al-Qur'an Pendidikan dan Pengajaran (Cet.I). Bandung : Pustaka Madani

Hatta Rajasa, M. 2007. Membangun Karakter dan Kemandirian Bangsa. Jakarta: Sekretariat Negara Republik Indonesia

Lubis, Muchtar. 2001. Manusia Indonesia. Jakarta: Yayasan Obor Indonesia

Ratna Megawangi, Dr. 2007. Semua Berakar Pada Karakter. Jakarta: Lembaga Penerbit FE-UI

Soemarno Soedarsono, H. 2009. Karakter Mengantarkan Bangsa dari Gelap Menuju Terang. Jakarta: Kompas Gramedia. 